\title{
Impact of Icelandic Volcano Ash on Air Travel in 2010 and Its Future Implications
}

\author{
Mohamed Nassar \\ Lecturer- Faculty of Tourism and Hotels, Alexandria University
}

\begin{abstract}
The research was done on the impact of Icelandic volcano ash upon the air travel in 2010 and its future implications. The volcano in question is situated on the Iceland glacier called Eyjafjallajokull. It started negligible volcanic activity on March 8, 2010 after many years of inactivity. However, these fiery eruptions renewed on April 15, 2010, and led to a consequent ban on air-traffic in UK for 6 consecutive days. The ban and attributed delays in flights caused commotion among the travelers and authorities. The airlines, economies, and people incurred huge monetary losses. Moreover, the indefinite cancellation of air traffic due to ash cloud in the Northern Europe was one of the biggest airline turmoil during a peace-period. Fiscal losses and emotional distress were the outcomes, along with the criticism by several analysts whether the complete shutting down of air space was justified or not. The primary research through survey questionnaires and in-depth interviews revealed that the travelers indeed suffered from huge financial losses in business and else. However, they lacked any sort of preparation like travel insurance, standby accommodation measures, etc. It was their unpreparedness that hit them even harder during this time. Scientists have predicted that future re-ignition of the ash cloud from Eyjafjallajokull and other neighboring volcanoes are expected. To avoid the same catastrophic shut down, the EasyJet Corporation has declared an effective detection device which can measure the safety limit and density of the ash cloud. Previous estimates by researchers were limited and not precise. Recommendations include the travel insurance for the passengers and attempt to stay vigilant, while the airlines can reinstate the goodwill be offering timely information and convenience to its clients. For achieving this, it's highly prudent to stay in special liaison with the meteorological centers worldwide.

Keywords: Eyjafjallajokull, Iceland volcano, ash cloud, UK air traffic ban, ash plume 2010

Impact of Icelandic Volcano Ash on Air Travel in 2010 and Its Future Implications

The literal meaning of a natural disaster is confined to any sort of calamity resultant from natural forces rather than through human actions e.g. volcanic eruption, tornadoes, lightening, floods, etc.
\end{abstract}

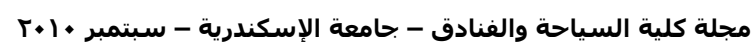


(Encarta ${ }^{\circledR}$ World English Dictionary, 2009). Connotatively, the significance of a natural disaster is derived from the impact it creates. For instance, an earthquake of Richter scale 2.3 is a form of natural disaster. However, it's not considered catastrophic due to its negligible magnitude. Volcanoes are the feared flaming eruptions from the lower layers of earth. The visible openings of volcanic mountains are the "vents" on the surface of Earth which emit magma, thick ash, and other gases, when active (Volcanoes, 2009). Furthermore, the National Geographic elaborates that the rocky mountainous structure surrounding the crater usually manifests due to the lava oozing out and hardening over a period of hundreds of years. The incidence of volcanic activity shows erratic pattern. Nearly 1,900 volcanoes around the globe are considered to be "active" as they have greater probability of exploding and wreaking havoc. Through the course of three centuries, nearly 26,000 people have fallen prey to volcanic eruptions (Volcanoes, 2009). The latest well-known volcanic activity was monitored in Europe at volcano situated under a glacier named Eyjafjallajokull. It gained media attention and scientific interest when the ash originating from the volcano created a widespread, dense plume of obnoxious gases and suspended particles. Apart from the environmental hazard poking from one of the less inhabited part of the world, the reason for a greater hype was made up when the ash cloud hovered above the air route crucial to British air travel. Other European air traffic also suffered from this, but the British were most affected. The closure of airplane flights continued for approximately six days, and the UK air space was reinstated with caution of April 20, 2010 (Fearnley, 2010). The action of closing down the air space was resultant of sheer panic and lack of safer options (New ash cloud disrupts UK, Ireland air travel, 2010). However, the safety rules were eased for Irish and British aviation to resume the air travel, but it did not help much to cover up for colossal losses (Volcano ash cloud: UK and Irish air safety rules eased, 2010). Nonetheless, such move had a grave impact upon Europe financially, socially and economically. The air commerce was completely halted during this time period, with people related in these fields incurred monetary and other losses. Moreover, the frustration among people due to cancellation of flights invoked outrage and stress (Ash-flow problems: Iceland's volcanic eruption., 2010). Hence, it can be deduced that the impact of a natural disaster does not just depend upon its relative magnitude, but it also encompasses other spheres of life, directly or indirectly.

The study is being done to understand impact of Icelandic volcano ash on air travel in 2010 and its future implications. 
The significance of this study is to evaluate the reaction of general public and to gauge the extent of such impact upon them. Moreover, it will reveal the interconnectedness of one event to all parts of the world, owing to the unprecedented globalization. It will also allow us to check whether there are any alternatives to closing down the air traffic if such incident repeats itself in future. Analysis of related information will quicken the steps of rational decision-making in similar scenarios.

\section{Research Questions \\ Primary Research Question}

The primary research question for this research was to find out how the Icelandic volcano (Eyjafjallajokull) affected air travel did and what are the related future implications of such natural disaster?

Subsidiary Research Questions

The subsidiary questions were formed by addressing the specific aspects of major research question. Consequently, the answers to these questions would synthesize to reject or accept the expected findings (hypothesis statement):

1. What is most common destination of travel and preferred mode of transportation?

2. Are the people aware of the precautions or previously affected by natural disasters?

3. Did the volcanic eruption of Eyjafjallajokull affect their intention of air travel?

4. In what ways can the impact be minimized or avoided?

5. What alternatives can be practically implemented if such situation occurs again?

\section{Literature Review}

The references to the dark plume of ash cloud were being persistently made after the Eyjafjallajokull volcano showed renewed fiery activity on April 14, 2010 (Walsh, Bryan, Dyk, Deirdre, Smith, \& Adam, 2010). Walsh et al. elaborate in their article in Time Magazine that the Eyjafjallajokull volcano was underrated as being the "weary old man" due to its inactivity. However, as the article mentions, the stirs were created on March 20, 2010, when the volcano erupted some spurts of ash, magma and gas fumes. It became a mild tourist attraction and then the hype died away as the volcano lapsed into peace. Nonetheless, the new eruptions closed down the major hubs of air traffic by April 15, 2010, when the ash cloud "loomed" over the

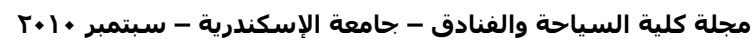


European continent (Walsh, Bryan, Dyk, Deirdre, Smith, \& Adam, 2010). The reasons attributing to the shutting down of air space were several. The foremost was the high altitude of Eyjafjallajokull glacier (which held the crater of the volcano). Also, the ash cloud contained suspended particles of silicates which have great tendency to damage the jet engines, hence increasing the risk of airplane crash (Clark, Robbins, Burns, Werdigier, Cowell, \& Jolly, 2010). The visibility problem due to dense ash cloud was another reason. The levels of volcanic activity declined around April 19, 2010, but the dissipating ash still below the admissible visibility range for aircrafts (Fearnley, 2010). Moreover, the clogging of fuel and cooling system along with the erosion of metallic structure of aircrafts contributed to such drastic precaution (Icelandic volcanic ash alert grounds UK flights, 2010). The BBC News also explained the severity of impact as:

"The UK's airspace restriction was the worst in UK's history. NATS (UK's air traffic control service) spokesmen said around 102,000 flights were cancelled and 7 million people were affected... Not only were travelers affected but also sports teams have been hit by travel problems and dozens of students were evacuated from accommodation in Iceland after the volcano eruption...Businesses also lost money through cancelled meetings, stranded staff, and delays to air mail...The most direct casualty of the ash is the airline industry. The International Air Transport Association (IATA) estimates that airlines were collectively losing $£ 130 \mathrm{~m}$ per day in lost revenues totaling at least $£ 1.2$ billion...Travel companies lost out too. TUI, the owner of Europe's biggest travel operator, says it was losing between $£ 5 \mathrm{~m}$ and $£ 6 \mathrm{~m}$ a day." (Icelandic volcanic ash alert grounds UK flights, 2010)

Apart from the losses in monetary terms, the "stranded travelers" also went through stressful journey or negative emotions towards the ban on European air-travel. Quoting the case of a German Chancellor, Angela Merkel, an article by Welsh et al. in April 2010 said "German Chancellor Angela Merkel, returning from San Francisco, was forced to fly to Grand Forks, N.D., then to Lisbon, then to Rome, and then travel by car and bus to Germany--an odyssey that took nearly three days. (Walsh, Bryan, Dyk, Deirdre, Smith, \& Adam, 2010)". Even though the safety was priority of the authorities, but to minimize the incurred losses the aircrafts "flew roundabout routes, lower altitudes or simply flew visual flight rules (VFR) to get to, or at least nearer, their destinations" (Larson \& George, 2010). The 
scientists insist that research over ash cloud phenomenon is imperative. If such mandatory steps are neglected, some future ash cloud in, say, America can cause greater damage to the overall economy. Moreover, precise measurements for the density of ash cloud from volcanic activity are not possible (Perkins \& Sid, 2003). Consequently, the allowable range of ash fume density, at which the air planes are at minimum risk, cannot be optimistically predicted (Walsh, Bryan, Dyk, Deirdre, Smith, \& Adam, 2010).

A tragedy for one can be a profit for someone else. Based on this principle, the substitute industry sectors for air travel enjoyed profits as the Icelandic volcano erupted to cause the ash plume across the Northern Europe. BBC reported in its case study about the Iceland's volcano activity and the associated outcomes that:

"...Travelers dealt with the situation by resorting to other methods of transportation. The companies benefited from the situation as travelers were looking for alternatives to flying. Ferry services have benefited from the flight restrictions... Eurostar in particular has seen huge demand from passengers since the disruption began on Thursday April 15th. The company said it carried 50,000 extra passengers on Thursday and Friday, an increase of nearly a third, with services effectively full. Over the weekend, it began laying on extra services, with six extra trains planned for travelers... Train services between Scotland and the south of England also reported a big rise in passenger numbers, as well as cross-channel ferry companies... P\&O ferries says its services between Spain, France, Holland and the UK were either full or close to full, with extra staff drafted in to the call centre to handle the huge volume of calls..." (Icelandic volcanic ash alert grounds UK flights, 2010)

The same case study from BBC cited that the tourism industry also suffered from magnified losses as the continent is one of the major tourist attractions. The countries like Greece were already facing turmoil in economy and social uproar, and the air travel crisis added fuel to the fiery fire (Icelandic volcanic ash alert grounds UK flights, 2010). Moreover, the British airlines faced havoc in reimbursing the airfares of people affected by the flight cancellation. It increased their administrative costs very high, plus the customer relationship experienced a severe blow (Pollock, 2010).

Research Methodology

Sample

The sample taken for the questionnaire survey for our research was 485 randomly selected individuals. There was prejudice to the age

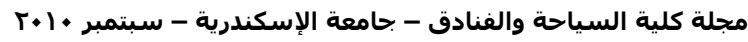


or any other associated factors while choosing respondents for questionnaires.

Research Tools

The data was collected through questionnaires, personal observation, interviews, internet search, and review of official documents. The primary data collection resources were qualitative exploratory research with in-depth interviews of 12 affected passengers. For quantifiable data, the survey questionnaires were floated to obtain the results. Furthermore, the insight into the whole scenario was achieved through case study analysis of Icelandic volcano and other natural disasters. The sources of such secondary information included reports and statistics from airlines, news articles and other authentic journal databases.

Data Analysis Procedures

The collected data was divided into objective and subjective information. The qualitative data from secondary research and the indepth interviews was analyzed to find out the connection between present literature and actual response from affected people. Moreover, the information obtained from primary sources like questionnaire was coded and converted into percentages for a better assessment of the composition of answers. Also, a Chi-squared test was performed for the acceptance or rejection of expected findings. The SPSS 17 statistical package was used to process all the data and tabulations used.

\section{Statistical Data Analysis}

The data collected through questionnaires was first coded and processed to form graphical representations of each question (Appendix A). The pie charts, bar graphs, etc. were predominantly used for this purpose. It would offer a quicker and aggregate analysis of the composition of the responses. More sophisticated relationship between variables was done through Chi-square test and crosstabulations.

Summarizing few main highlights of the results, the age-group with most participants is 20-29 years old (Figure 1, Appendix A). Majority of the respondents i.e. 52\% travel 2-4 times in a year for leisure, business and/or other purposes (Figure 2, Appendix A). For such people, the most frequent destination of travel is usually Europe (Figure 3, Appendix A). Since the most affected air traffic was in Europe, this result gives us a rough idea that the passengers might have been stranded and/or cancelled their plans. The modern international travel is no longer done through sea voyage as the majority of people prefer the easier and quicker air travel (Figure 4,

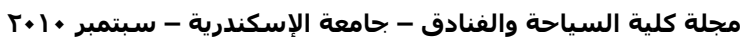


Appendix A). Regardless of their frequent international air travel, 435 respondents among 485 had no travel insurance whatsoever (Figure 5, Appendix A). Such result depicts that majority of people take the air travel industry for granted and appear hugely optimistic about it. This behavior is present because $91 \%$ of the people have not been previously affected by any sort of natural disaster before (Figure 6, Appendix A). However, when these participants directly or indirectly experienced the chaos of ban on air travel for 6 days in UK due to plume of ash cloud, they admitted to have changed their intentions about traveling (Figure 7, Appendix A). Most of the participants, however, plan their trips ahead of time, so any hurdle in their travelling causes emotional, mental and physical frustration to them (Figure 8, Appendix A).

Chi-square test was used to test the association of variables. Chi-square test is a useful way of looking at the relationship between two nominal (or categorical) variables in order to cross-classify the data and get a count of the number of cases sharing a given combination of levels (i.e., categories), and then create a contingency table showing the levels and the counts. A chi-square probability of .05 or less is commonly interpreted as justification for rejecting the null hypothesis that the row variable is unrelated to the column variable.

When performing a chi-square test, the data must satisfy the following assumptions:

1. The sample must be randomly selected from the population.

2. The sample size, $n$, must be large enough so that the expected count in each cell is greater than or equal to 5 .

In cases where chi-square tests were not valid, contingency coefficient (for nominal data) and Spearman's Rho (for ordinal data) were used. The contingency coefficient is a Chi-square-based measure of the relation between two categorical variables. Its range is always limited to 0 through 1 , where 0 means complete independence. Spearman's value on the other hand, ranges from -1 to +1 . A 0 value also means complete independence or lack of relationship between variables. (Table1 \& Table 2, Appendix B)

As the results in Table 1, Appendix B show that most of the independent variables have weak correlation with the dependent variable (Impact of natural disasters on travelers). The Chi-square test does not hold valid in all cases as one of the two prerequisites are not fulfilled. The Table 2 results also depict that the variables on which Chi-squared test are applicable, the alpha (significance level of 5\%) is

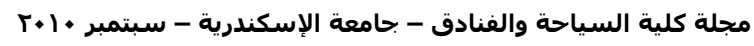


not greater than the $\mathrm{p}$-values of respective variables, hence we fail to reject the null hypothesis.

The cross tabulation linkages are established (Table 3-15, Appendix B) through disaggregated data of the variables taken for the Chi-square tests. Through our statistical evaluation, it's revealed that age, frequency of travel, destination, mode of transportation, presence of travel insurance and planning of trips ahead of time have weak correlation or association with impact of natural disaster to travelers. Meanwhile, the same set of variables has no association with their intention to travel given the eruption of volcano in Iceland. This generally showed that these factors do not affect travelers' travelling decisions. An example of cross-tabulated results is: Majority (92\%) of the respondents have not yet experienced severe impact of any natural disaster. However, among those $(8 \%)$ who have been affected already by a natural disaster are travelers:

- Belonging to the 20-29 years old age group (4.3\%)

- Who travel 2-4 times a year (3.9\%)

- Whose destinations are in Europe (3.3\%)

- Who travel by plane $(6.2 \%)$

- Without travel insurance $(6.4 \%)$

- Who plan their trips ahead of time $(4.7 \%)$

Even though the aggregated responses showed that people are cautious of air travel in times of calamity, but they are more likely to be distressed severely by such natural disasters as they lack in preparedness. For instance, the people neglect travel insurance as a part of their safety. People who are not previously affected by any disaster are overly optimistic and there are nearly $82 \%$ of people who don't have travel insurance because they haven't experienced any natural catastrophe during travel as yet.

\section{Subjective Data Analysis}

From subjective analysis of the qualitative data through indepth interviews of 12 people, the deductions from our statistical outputs were confirmed. The selection criterion for interview candidates was that they were directly affected by the volcanic eruptions from Icelandic volcano as their air travel was hampered. The interview respondents were asked similar questions as those mentioned in the questionnaire, but in an unstructured and discussion manner to have an insight of their thoughts.

The first important result of such interviews was that people were indeed unprepared for any sort of natural disaster. They were into an oblivion regarding the volcanic activity of Eyjafjallajokull

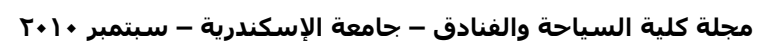


until their respective flights have been cancelled due to the severity of the problem. Moreover, the majority admitted to be frequent business travelers with their common destination being Europe and North America for work-related tours. The participants reported to be more cautious of their personal safety after the $9 / 11$ events, but they did not use to pay much regard towards any natural disaster like volcanic eruptions, tornadoes, lightening etc. being a hurdle in their traveling plan. The floods, hurricanes and earthquakes were the main calamities that were known to be more potent of disturbing their life than any ash cloud. However, they confirmed that they were now aware of the hazards that are brought in by other forms of catastrophes.

As the travelers were unprepared for such emergencies, they had not hedged against the financial losses they incurred due to ban on air-travel for six days. Such losses manifested as they were unable to attend a particular meeting abroad. Some could not show up for a work opportunity and for other people, the raw materials and/or supplies could not reach in time for the business demand. Regardless of the nature of the business, people suffered from some degree of financial turmoil. Other respondents who had to visit their friends and families for some important events reported emotional distress and frustration over their failure to show up at a celebration and/or funeral, etc.

Apart from the monetary loss, the utter state of chaos was debilitating for the travelers. They were offered uncertain and incomplete information regarding the nature and extent of the ash cloud delays. The lack of information was irksome as people were unable to take any specific measures like take an extension from a job interview, etc. The authorities told that the ban was for an indefinite period, so the impending losses magnified the state of commotion. Some people also notified that they had to reach home through tiring long routes on their way out of Europe, others confirmed to be stranded with several people upon the air-port before the ban was actually implemented.

These travelers were discontented with the way the situation was handled and lamented the fact that they were not remunerated for losses where possible. However, the people were largely unaware of the problems an ash cloud with suspended harmful particles can cause a plane. With a exception of two people, the respondents did not understand the limitations the authorities came across while taking a sweeping measure of banning the air-traffic altogether. Again, the people still considered the travel insurance after this event an unnecessary expense. They were of the opinion that such things are

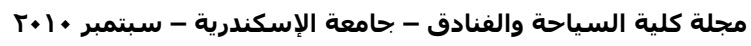


not so easily repeated in near-future. Nonetheless, a couple of participants agreed to the significance of travel insurance for their own safety and a hedge for their monetary losses.

\section{Conclusion}

\section{Expected Findings}

Prior to this study, it was a generally known through media coverage and the word-of-mouth that the volcanic ash cloud from Eyjafjallajokull is certainly one of the bigger natural disasters of 2010 that affected globally. The earthquake in Haiti claimed human lives but the direct effect of that tragedy was somewhat confined to their geographical region. However, fortunately, the volcano of Eyjafjallajokull did not cause any casualties, yet impacted severely to cause billions of pounds being lost.

Through the exploratory research, it was expected that the people would certainly view the future outlook of airplane industry differently now. However, the results revealed that Icelandic volcano caused them emotional, financial and other distress, but the magnitude of such impact was mainly due to their own unpreparedness. The passengers were caught off guard and they had no hedge against their fiscal losses. The statistical and qualitative analysis of primary data revealed that the significant relationship is not present between the variables like age and the intention to travel, travel insurance, etc.

Consequently, the first part of our primary research question is covered that entailed the type of effect of Eyjafjallajokull volcano upon air travel and passengers. The results depicted that lack of vigilance and precautions before such unforeseen debacle caused huge monetary and psychological anguish.

\section{Future Implications}

The concerned authorities were also a victim of sudden mayhem when the renewed volcanic activity resulted in the mid of April 2010. During this state of commotion, they were unable to take appropriate measurements of the intensity and future outcome of the plume of ash cloud over Eyjafjallajokull. Hence, it was reported by researchers that a neighboring volcano of Eyjafjallajokull named Katla can be the next one to cause a similar problem in near future (Leake \& Hastings, 2010).

For better future prospects, there is a dire need of proper detection methods/devices. These measures can accurately inform the related researchers regarding the density of ash cloud, in the wake of chaos. A promising new technology in this case is the Airborne

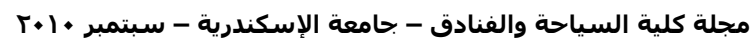


Volcanic Object Identifier and Detector (AVOID) by easyJet corporation. It was announced in a press release by the company on June 4, 2010 that they would introduce the AVOID for official researchers to practically use it in case of any future ash cloud situation (easyJet Press Release, 2010). The author Young elaborated in her published article:

"In essence it is a radar system but one designed to identify volcanic ash rather than weather patterns. Infrared technology will be used to identify areas where volcanic (or other) ash is present and to measure its density, allowing the pilots to alter their flight path of the cloud is determined to be too dense for safety... it is hoped that in the longer term, the ash cam will be installed on commercial aircraft, rather than the initial two test planes on which it will be trialled. In this way, it should be possible to minimize, although not in extreme cases to avoid, disruption on the scale of that experienced in April." (Young, 2010)

\section{Recommendations for Travelers}

It is highly recommended for all types of travelers to possess travel insurance because it can sufficiently cover for any unforeseen trip cancellation. The interruptions and delay in the air travel owing to some catastrophic events can also result in reimbursements for the costs incurred. Other facilities attributed to this can be convenient hotel accommodations and meals up to certain defined limit by the type of service plan the traveler may have.

Moreover, a positive approach is to plan ahead of time (which many people in our study did), but also make tentative adjustments for any unpredictable event that might come in the way. There should always be a provision or hedge against the loss can occur if things do not go ideally. These things include tentative reservations at hotels or other accommodations. Furthermore, having emergency numbers to your airport, airlines and travel agency is crucial because in case of any rumor or doubt, the passenger can always confirm with the officials. Relying on hype is not a prudent move in this case. It is always advisable to travel with someone whether friend, family or coworker when possible. Being stranded alone and out of contact surely makes matters worse psychologically for everyone.

Being vigilant is the key. If a passenger is a seasoned traveler or has high stakes upon air traffic for business purposes, it's better to stay informed regarding any impending disaster warnings. Keeping up to date with the news would allow the person to catch timely warning by authorities.

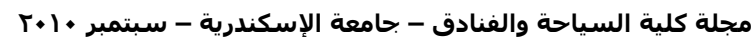




\section{Recommendations for Transportation Firms and Airlines}

It would certainly be a wise move for all the airlines to be associated with the meteorological center on a regular basis. Apart from the daily updates that are necessary for any flights, special liaison is recommended since the scientists have offered a prediction of possible ash clouds in near future. It's always prudent to be prepared beforehand to avoid last minute hassle.

Another possible solution for active decision-making is to maintain and update database containing the pertinent details of the passengers registered for the flights. Moreover, this would allow the respective companies to reach and inform the clients in a timely manner regarding the cancellation of their flights or the change in timings. This would not only restore the goodwill of the airline, but also save from draining customer service activity.

The air traffic is increasing every day as new airlines are being set up and people are acquiring their private jets for frequent travel if they can afford such luxury. In the wake of such overcrowding, the airlines must develop series of alternate route to the same destination in case any type of natural disaster hits a region.

Regardless of such measures, a catastrophe can always strike unannounced. So, in such scenario, the airlines should always keep hotel accommodations on standby, if the flights are delayed and cause inconvenience to the travelers. 


\section{References}

Ash-flow problems: Iceland's volcanic eruption. (2010). Global Agenda, 60. Clark, N., Robbins, L., Burns, J. F., Werdigier, J., Cowell, A., \& Jolly, D. (2010, April 16). Volcanic Ash grounds Air Traffic in Northern Europe. New York Times, p. 1.

easyJet Press Release. (2010, June 4). Retrieved July 26, 2010, from easyJet corp.: http://corporate.easyjet.com

Encarta ${ }^{\circledR}$ World English Dictionary. (2009). Retrieved June 14, 2010, from MSN Encarta: http://encarta.msn.com/dictionary_ 1861696697 /natural_disaster.html

Fearnley, C. (2010, April 22). A Fallout from the Ash Cloud. Retrieved June 13, 2010, from Aon Benfield UCL Hazard Research Centre: http://www.abuhrc.org/Pages/index.aspx

Icelandic volcanic ash alert grounds UK flights. (2010, April 15). Retrieved June $30, \quad 2010$, from BBC News UK: http://news.bbc.co.uk/2/hi/8621407.stm

Larson, \& George. (2010, April 26). An 'Exercise in Creativity'. Aviation Week \& Space Technology.

Leake, J., \& Hastings, C. (2010, May 16). Scientists Forecast Decades of Ash Clouds. Retrieved July 20, 2010, from Sunday Times: http://www.timesonline.co.uk

New ash cloud disrupts UK, Ireland air travel. (2010, May 16). Retrieved June 12, 2010, from REUTERS: http://www.reuters.com article/idUSTRE64F0W420100516

Perkins, \& Sid. (2003, September 13). Danger in the Air. Science News .

Pollock, I. (2010, June 3). Volcanic ash: Passengers face repayment delays. Retrieved June 30, 2010, from BBC NEWS: http://www.bbc.co.uk/news/10216236

Volcano ash cloud: UK and Irish air safety rules eased. (2010, May 11). Retrieved June 30, 2010, from BBC UK: http://news.bbc.co.uk/2/hi/business/10216236.stm

Volcanoes. (2009). Retrieved June 15, 2010, from National Geographic: Environment:

http://environment.nationalgeographic.com/environment/naturaldisasters/volcano-profile/

Walsh, Bryan, Dyk, V., Deirdre, Smith, \& Adam. (2010, May 3). The Cloud That Closed A Continent. Time , pp. 34-35.

Young, J. (2010, June 6). New Technology May Prevent Future Ash Cloud Air Travel Chaos. Retrieved July 28, 2010, from Suite 101: http://news.suite101.com/article.cfm/new-technology-may-preventfuture-ash-cloud-air-travel-chaos-a245303 


\section{Appendix A}

Table 1

Chi-Square Test to assess the impact of natural disaster on travelers

\begin{tabular}{lllll}
\hline & \multicolumn{3}{l}{ Impact of natural disaster on travelers } & \\
\cline { 2 - 5 } Variables & $\begin{array}{l}\text { Chi- } \\
\text { square } \\
\text { statistics }\end{array}$ & $\begin{array}{l}\text { p- } \\
\text { value }\end{array}$ & $\begin{array}{l}\text { Contingency } \\
\text { coefficient/Spearman's }\end{array}$ & $\begin{array}{l}\text { p- } \\
\text { value }\end{array}$ \\
\hline Age & NA & -0.031 & 0.495 \\
\hline Frequency of travel & NA & -0.054 & 0.232 \\
\hline $\begin{array}{l}\text { Destination } \\
\text { travel }\end{array}$ & of & NA & 0.121 & 0.208 \\
\hline $\begin{array}{l}\text { Mode } \\
\text { transportation }\end{array}$ & NA & 0.071 & 0.297 \\
\hline $\begin{array}{l}\text { Travel insurance } \\
\text { Planning of } \\
\text { ahead of time }\end{array}$ & NA & NA & 0.078 & 0.086 \\
\hline *NA-Test invalid or not applicable; assumptions did not meet & 0.784 \\
\hline
\end{tabular}

Table 2

Chi-Square Test to evaluate the effect of volcano in Iceland on travelers' intention to travel

\begin{tabular}{|c|c|c|c|c|}
\hline \multirow[b]{2}{*}{ Variables } & \multicolumn{4}{|c|}{$\begin{array}{l}\text { Effect of volcano in Iceland on travelers' } \\
\text { intention to travel }\end{array}$} \\
\hline & $\begin{array}{l}\text { Chi- } \\
\text { square } \\
\text { statistics }\end{array}$ & $\begin{array}{l}\text { p- } \\
\text { value }\end{array}$ & $\begin{array}{l}\text { Contingency } \\
\text { coefficient/Spearman's }\end{array}$ & $\begin{array}{l}\text { p- } \\
\text { value }\end{array}$ \\
\hline Age & NA & & 0.036 & 0.427 \\
\hline Frequency of travel & NA & & 0.032 & 0.488 \\
\hline $\begin{array}{l}\text { Destination of } \\
\text { travel }\end{array}$ & 8.385 & 0.136 & 0.130 & 0.136 \\
\hline $\begin{array}{ll}\text { Mode } & \text { of } \\
\text { transportation }\end{array}$ & 2.486 & 0.289 & 0.071 & 0.289 \\
\hline Travel insurance & 0.002 & 0.964 & 0.002 & 0.964 \\
\hline $\begin{array}{l}\text { Planning of trips } \\
\text { ahead of time }\end{array}$ & 1.853 & 0.396 & 0.062 & 0.396 \\
\hline
\end{tabular}


Table 3

The change in travel intentions according to specific age-groups

\begin{tabular}{|c|c|c|c|}
\hline \multirow[t]{2}{*}{ Age } & \multicolumn{2}{|c|}{$\begin{array}{l}\text { Has the volcano in } \\
\text { Iceland changed your } \\
\text { intentions about travel }\end{array}$} & \multirow[t]{2}{*}{ Total } \\
\hline & yes & no & \\
\hline \multirow{2}{*}{$20-29$} & 213 & 78 & 291 \\
\hline & $43.9 \%$ & $16.1 \%$ & $60.0 \%$ \\
\hline \multirow{2}{*}{$30-39$} & 70 & 27 & 97 \\
\hline & $14.4 \%$ & $5.6 \%$ & $20.0 \%$ \\
\hline \multirow{2}{*}{$40-49$} & 42 & 16 & 58 \\
\hline & $8.7 \%$ & $3.3 \%$ & $12.0 \%$ \\
\hline \multirow{2}{*}{50} & 25 & 14 & 39 \\
\hline & $5.2 \%$ & $2.9 \%$ & $8.0 \%$ \\
\hline \multirow{2}{*}{ Total } & 350 & 135 & 485 \\
\hline & $72.2 \%$ & $27.8 \%$ & $100.0 \%$ \\
\hline
\end{tabular}

Table 4

The change in travel intentions with respect to frequency of travel

\begin{tabular}{|c|c|c|c|}
\hline \multirow[t]{2}{*}{ Frequency of Travel } & \multicolumn{2}{|c|}{$\begin{array}{l}\text { Has the volcano in } \\
\text { Iceland changed your } \\
\text { intentions about travel }\end{array}$} & \multirow[t]{2}{*}{ Total } \\
\hline & yes & no & \\
\hline \multirow{2}{*}{ once a year } & 185 & 67 & 252 \\
\hline & $38.1 \%$ & $13.8 \%$ & $52.0 \%$ \\
\hline \multirow{2}{*}{ 2-4 times a year } & 110 & 44 & 154 \\
\hline & $22.7 \%$ & $9.1 \%$ & $31.8 \%$ \\
\hline \multirow{2}{*}{5 times a year } & 55 & 24 & 79 \\
\hline & $11.3 \%$ & $4.9 \%$ & $16.3 \%$ \\
\hline \multirow{2}{*}{ Total } & 350 & 135 & 485 \\
\hline & $72.2 \%$ & $27.8 \%$ & $100.0 \%$ \\
\hline
\end{tabular}


Table 5

The effect of destination of travel upon the intention to travel

\begin{tabular}{|c|c|c|c|}
\hline \multirow[t]{2}{*}{ Destination of Travel } & \multicolumn{2}{|c|}{$\begin{array}{l}\text { Has the volcano in } \\
\text { Iceland changed your } \\
\text { intentions about travel }\end{array}$} & \multirow[t]{2}{*}{ Total } \\
\hline & yes & no & \\
\hline \multirow{2}{*}{ Europe } & 116 & 40 & 156 \\
\hline & $23.9 \%$ & $8.2 \%$ & $32.2 \%$ \\
\hline \multirow{2}{*}{ Asia/Middle East } & 88 & 48 & 136 \\
\hline & $18.1 \%$ & $9.9 \%$ & $28.0 \%$ \\
\hline \multirow{2}{*}{ North America } & 62 & 15 & 77 \\
\hline & $12.8 \%$ & $3.1 \%$ & $15.9 \%$ \\
\hline \multirow{2}{*}{ Africa } & 45 & 13 & 58 \\
\hline & $9.3 \%$ & $2.7 \%$ & $12.0 \%$ \\
\hline \multirow{2}{*}{ Australia } & 26 & 13 & 39 \\
\hline & $5.4 \%$ & $2.7 \%$ & $8.0 \%$ \\
\hline \multirow{2}{*}{ South America } & 13 & 6 & 19 \\
\hline & $2.7 \%$ & $1.2 \%$ & $3.9 \%$ \\
\hline \multirow{2}{*}{ Total } & 350 & 135 & 485 \\
\hline & $72.2 \%$ & $27.8 \%$ & $100.0 \%$ \\
\hline
\end{tabular}

Table 6

The effect of mode of transportation in intentions about travel

\begin{tabular}{|c|c|c|c|}
\hline \multirow[t]{2}{*}{ Mode of Transportation } & \multicolumn{2}{|c|}{$\begin{array}{l}\text { Has the volcano in } \\
\text { Iceland changed your } \\
\text { intentions about travel }\end{array}$} & \multirow[t]{2}{*}{ Total } \\
\hline & yes & no & \\
\hline \multirow{2}{*}{ airplane } & 285 & 118 & 403 \\
\hline & $58.8 \%$ & $24.3 \%$ & $83.1 \%$ \\
\hline \multirow{2}{*}{ car } & 49 & 13 & 62 \\
\hline & $10.1 \%$ & $2.7 \%$ & $12.8 \%$ \\
\hline \multirow{2}{*}{ bus } & 16 & 4 & 20 \\
\hline & $3.3 \%$ & $.8 \%$ & $4.1 \%$ \\
\hline \multirow{2}{*}{ Total } & 350 & 135 & 485 \\
\hline & $72.2 \%$ & $27.8 \%$ & $100.0 \%$ \\
\hline
\end{tabular}

مجلة كلية السياحة والفنادق - جامعة الإسكندرية - سبتمبر • ( • (88) 
Table 7

The effect of travel insurance on intentions about travel

\begin{tabular}{|c|c|c|}
\hline \multirow[t]{2}{*}{$\begin{array}{l}\text { Do you have travel } \\
\text { insurance }\end{array}$} & $\begin{array}{l}\text { Has the volcano in iceland } \\
\text { changed your intentions about } \\
\text { travel }\end{array}$ & \multirow[t]{2}{*}{ Total } \\
\hline & yes & \\
\hline \multirow{2}{*}{ yes } & 42 & 58 \\
\hline & $3.3 \%$ & $12.0 \%$ \\
\hline \multirow{2}{*}{ no } & 308 & 427 \\
\hline & $63.5 \%$ & $88.0 \%$ \\
\hline \multirow{2}{*}{ Total } & 350 & 485 \\
\hline & $72.2 \%$ & $100.0 \%$ \\
\hline \multicolumn{3}{|c|}{$\begin{array}{l}\text { Table } 8 \\
\text { The effect of preplanned trips on the intention about travel }\end{array}$} \\
\hline \multirow[t]{2}{*}{$\begin{array}{l}\text { Do you plan your } \\
\text { trips ahead of time }\end{array}$} & $\begin{array}{l}\text { Has the volcano in Iceland } \\
\text { changed your intentions about } \\
\text { travel }\end{array}$ & Total \\
\hline & yes $\quad$ no & \\
\hline \multirow[b]{2}{*}{ yes } & 209 & 281 \\
\hline & $14.8 \%$ & $57.9 \%$ \\
\hline \multirow{2}{*}{ sometimes } & 92 & 131 \\
\hline & $19.0 \%$ & $27.0 \%$ \\
\hline \multirow{2}{*}{ never } & 49 & 73 \\
\hline & $10.1 \%$ & $15.1 \%$ \\
\hline \multirow{2}{*}{ Total } & 350 & 485 \\
\hline & $27.8 \%$ & $100.0 \%$ \\
\hline
\end{tabular}

Table 9

The effect of age on previous disaster experiences

\begin{tabular}{|c|c|c|c|}
\hline \multirow[t]{2}{*}{ Age } & \multicolumn{2}{|c|}{$\begin{array}{l}\text { Have you ever been affected } \\
\text { by natural disasters }\end{array}$} & \multirow[t]{2}{*}{ Total } \\
\hline & yes & No & \\
\hline \multirow{2}{*}{$20-29$} & 21 & 270 & 291 \\
\hline & $4.3 \%$ & $55.7 \%$ & $60.0 \%$ \\
\hline \multirow{2}{*}{$30-39$} & 9 & 88 & 97 \\
\hline & $1.9 \%$ & $18.1 \%$ & $20.0 \%$ \\
\hline \multirow{2}{*}{$40-49$} & 7 & 51 & 58 \\
\hline & $1.4 \%$ & $10.5 \%$ & $12.0 \%$ \\
\hline \multirow{2}{*}{50} & 2 & 37 & 39 \\
\hline & $.4 \%$ & $7.6 \%$ & $8.0 \%$ \\
\hline \multirow{2}{*}{ Total } & 39 & 446 & 485 \\
\hline & $8.0 \%$ & $92.0 \%$ & $100.0 \%$ \\
\hline
\end{tabular}


Table 10

The effect of frequency of travel on previous natural disaster experiences

\begin{tabular}{llll}
\hline \multirow{2}{*}{ Frequency of Travel } & \multicolumn{2}{l}{$\begin{array}{l}\text { Have you ever been } \\
\text { affected by } \\
\text { disasters }\end{array}$} & \multicolumn{2}{c}{ natural } & Total \\
\cline { 2 - 3 } & yes & no & \\
\hline once a year & 15 & 237 & 252 \\
\hline \multirow{2}{*}{$2-4$ times a year } & $3.1 \%$ & $48.9 \%$ & $52.0 \%$ \\
\hline \multirow{2}{*}{5 times a year } & 19 & 135 & 154 \\
\hline \multirow{2}{*}{ Total } & $3.9 \%$ & $27.8 \%$ & $31.8 \%$ \\
\hline
\end{tabular}

Table 11

The effect of destination of travel on natural disaster experiences

\begin{tabular}{|c|c|c|c|}
\hline \multirow[t]{2}{*}{ Destination of Travel } & \multicolumn{2}{|c|}{$\begin{array}{l}\text { Have you ever been } \\
\text { affected by natural } \\
\text { disasters }\end{array}$} & \multirow[t]{2}{*}{ Total } \\
\hline & yes & No & \\
\hline \multirow{2}{*}{ Europe } & 16 & 140 & 156 \\
\hline & $3.3 \%$ & $28.9 \%$ & $32.2 \%$ \\
\hline \multirow{2}{*}{ Asia/Middle East } & 7 & 129 & 136 \\
\hline & $1.4 \%$ & $26.6 \%$ & $28.0 \%$ \\
\hline \multirow{2}{*}{ North America } & 3 & 74 & 77 \\
\hline & $.6 \%$ & $15.3 \%$ & $15.9 \%$ \\
\hline \multirow{2}{*}{ Africa } & 5 & 53 & 58 \\
\hline & $1.0 \%$ & $10.9 \%$ & $12.0 \%$ \\
\hline \multirow{2}{*}{ Australia } & 5 & 34 & 39 \\
\hline & $1.0 \%$ & $7.0 \%$ & $8.0 \%$ \\
\hline \multirow{2}{*}{ South America } & 3 & 16 & 19 \\
\hline & $.6 \%$ & $3.3 \%$ & $3.9 \%$ \\
\hline \multirow{2}{*}{ Total } & 39 & 446 & 485 \\
\hline & $8.0 \%$ & $92.0 \%$ & $100.0 \%$ \\
\hline
\end{tabular}

Table 12

مجلة كلية السياحة والفنادق - جامعة الإسكندرية - سبتمبر • + T (90) 
The effect of the preferred mode of transportation on natural disasters

\begin{tabular}{|c|c|c|c|}
\hline \multirow[t]{2}{*}{ Mode of Transportation } & \multicolumn{2}{|c|}{$\begin{array}{l}\text { Have you ever been } \\
\text { affected by natural } \\
\text { disasters }\end{array}$} & \multirow[t]{2}{*}{ Total } \\
\hline & yes & No & \\
\hline \multirow{2}{*}{ airplane } & 30 & 373 & 403 \\
\hline & $6.2 \%$ & $76.9 \%$ & $83.1 \%$ \\
\hline \multirow{2}{*}{ Car } & 8 & 54 & 62 \\
\hline & $1.6 \%$ & $11.1 \%$ & $12.8 \%$ \\
\hline \multirow{2}{*}{ Bus } & 1 & 19 & 20 \\
\hline & $.2 \%$ & $3.9 \%$ & $4.1 \%$ \\
\hline \multirow{2}{*}{ Total } & 39 & 446 & 485 \\
\hline & $8.0 \%$ & $92.0 \%$ & $100.0 \%$ \\
\hline
\end{tabular}

Table 13

The effect of travel insurance on previous natural disasters

\begin{tabular}{|c|c|c|c|c|}
\hline \multirow[t]{2}{*}{$\begin{array}{l}\text { Do you } \\
\text { insurance }\end{array}$} & \multirow[t]{2}{*}{ have } & \multicolumn{2}{|c|}{$\begin{array}{l}\text { Have you ever been } \\
\text { affected by natural } \\
\text { disasters }\end{array}$} & \multirow[t]{2}{*}{ Total } \\
\hline & & yes & no & \\
\hline \multirow{2}{*}{ yes } & & 8 & 50 & 58 \\
\hline & & $1.6 \%$ & $10.3 \%$ & $12.0 \%$ \\
\hline \multirow{2}{*}{ No } & & 31 & 396 & 427 \\
\hline & & $6.4 \%$ & $81.6 \%$ & $88.0 \%$ \\
\hline \multirow{2}{*}{ Total } & & 39 & 446 & 485 \\
\hline & & $8.0 \%$ & $92.0 \%$ & $100.0 \%$ \\
\hline
\end{tabular}

Table 14

The effect of the intentions about travel on previous disasters

\begin{tabular}{llll}
\hline \multirow{2}{*}{$\begin{array}{l}\text { Has the volcano in Iceland } \\
\text { changed your intentions } \\
\text { about travel }\end{array}$} & $\begin{array}{l}\text { Have you ever been } \\
\text { affected by natural } \\
\text { disasters }\end{array}$ & \multicolumn{2}{c}{ Total } \\
\cline { 2 - 3 } & yes & no & \\
\hline \multirow{2}{*}{ Yes } & 28 & 322 & 350 \\
\hline \multirow{2}{*}{ No } & $5.8 \%$ & $66.4 \%$ & $72.2 \%$ \\
\hline \multirow{2}{*}{ Total } & 11 & 124 & 135 \\
\hline & $2.3 \%$ & $25.6 \%$ & $27.8 \%$ \\
\hline
\end{tabular}

Table 15

مجلة كلية السياحة والفنادق - جامعة الإسكندرية - سبتمبر • +؟؟ 
The impact of preplanning the trips on previous disasters

\begin{tabular}{llll}
\hline \multirow{2}{*}{$\begin{array}{l}\text { Do you plan your trips } \\
\text { ahead of time }\end{array}$} & $\begin{array}{l}\text { Have you ever been } \\
\text { affected by natural } \\
\text { disasters }\end{array}$ & \multicolumn{2}{c}{ Total } \\
\cline { 2 - 4 } yes & No & \\
\hline \multirow{2}{*}{ Yes } & 23 & 258 & 281 \\
\hline \multirow{2}{*}{ sometimes } & $4.7 \%$ & $53.2 \%$ & $57.9 \%$ \\
\hline \multirow{2}{*}{ never } & 9 & 122 & 131 \\
\hline \multirow{2}{*}{ Total } & $1.9 \%$ & $25.2 \%$ & $27.0 \%$ \\
\hline
\end{tabular}

مجلة كلية السياحة والفنادق - جامعة الإسكندرية - سبتمبر • + ب (92) 
Appendix B

Figure 1

Questionnaire Results: Age of participants

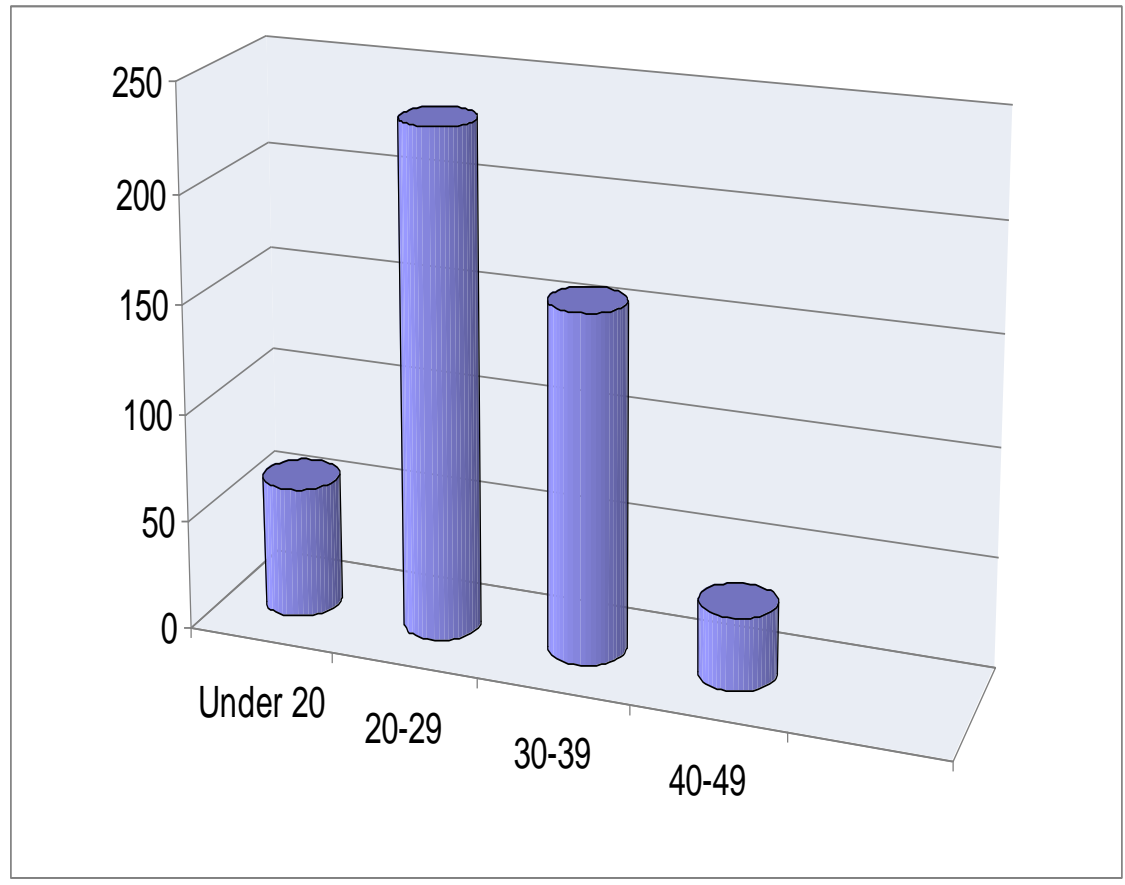

Figure 2

Questionnaire Results: Frequency of Travel

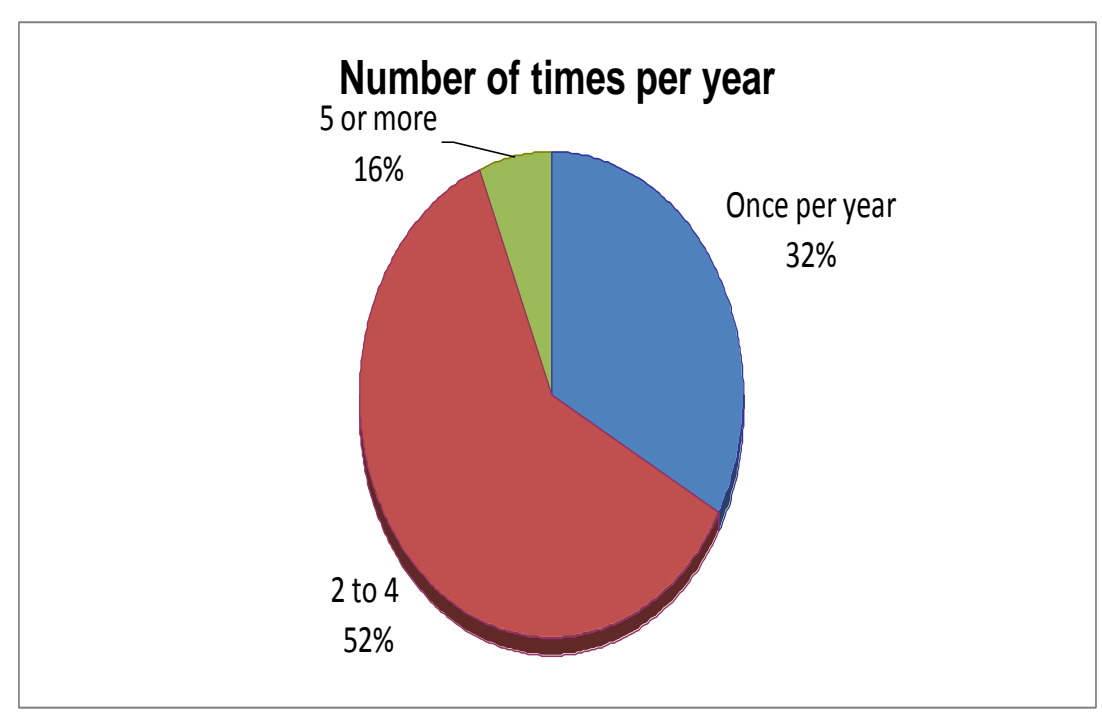

$\Gamma+1$

(93) 
Figure 3

Questionnaire Results: Destination

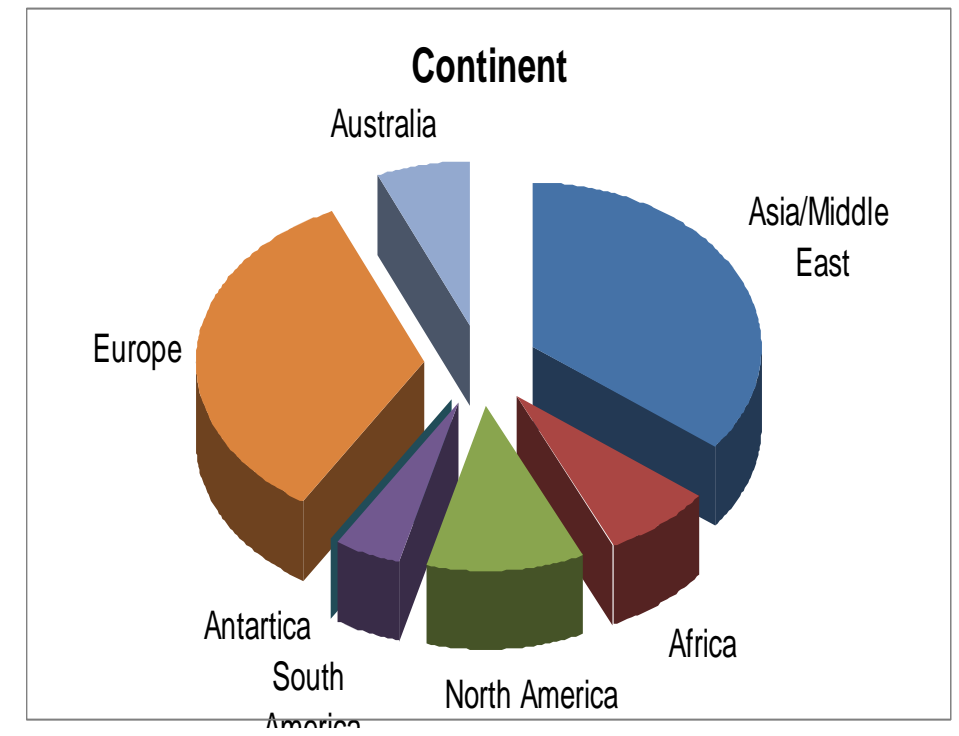

Figure 4

Questionnaire Results: Mode of Transportation

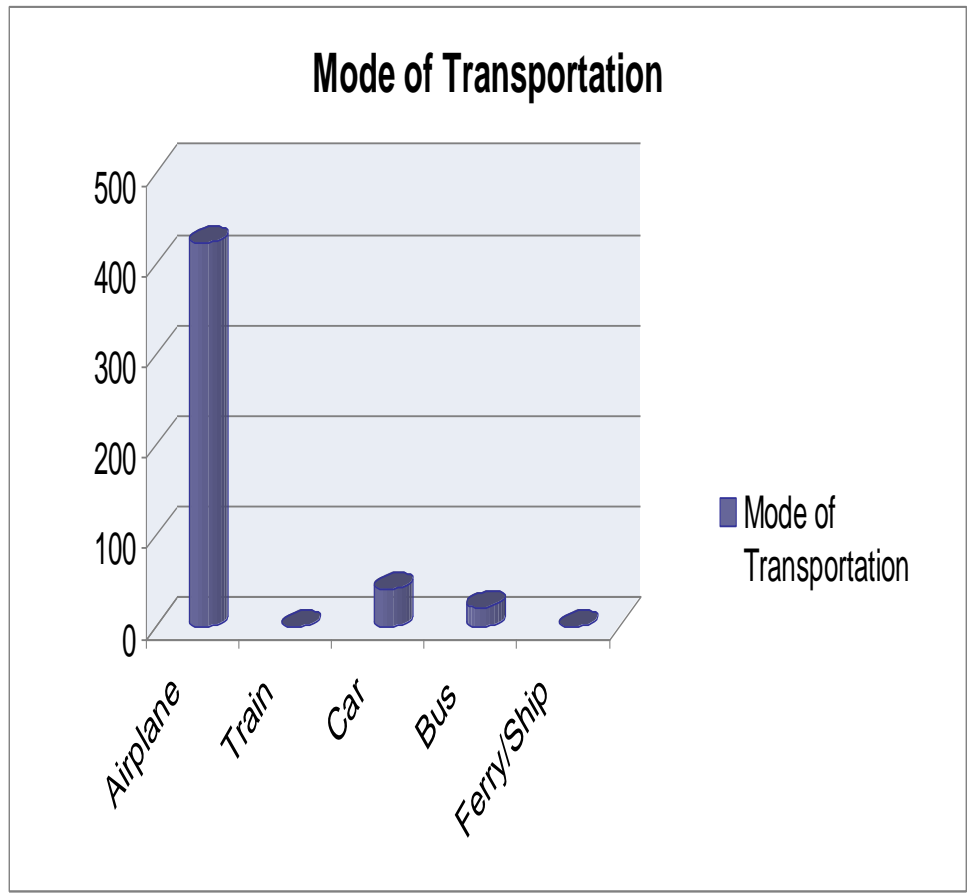

(94)

مجلة كلية السياحة والفنادق - جامعة الإسكندرية - سبتمبر • 1 † 
Figure 5

Questionnaire Results: Do you have travel insurance?

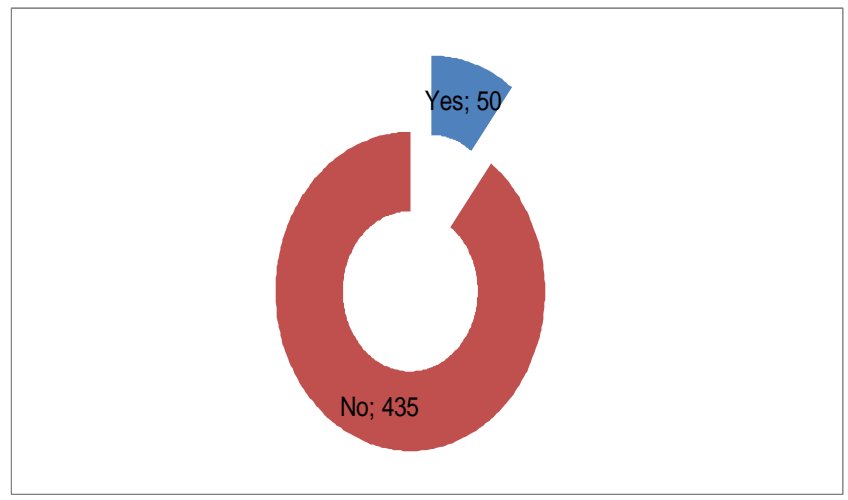

Figure 6

Questionnaire Results: Have you ever been affected by natural disasters?

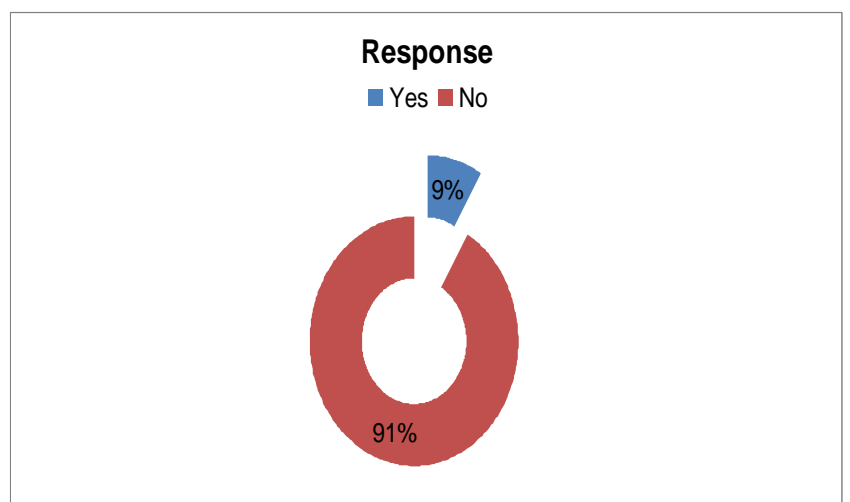

$\Gamma \cdot 1 \cdot$ 
Figure 7

Questionnaire Results: Has the volcano in Iceland changed your intentions about travel?

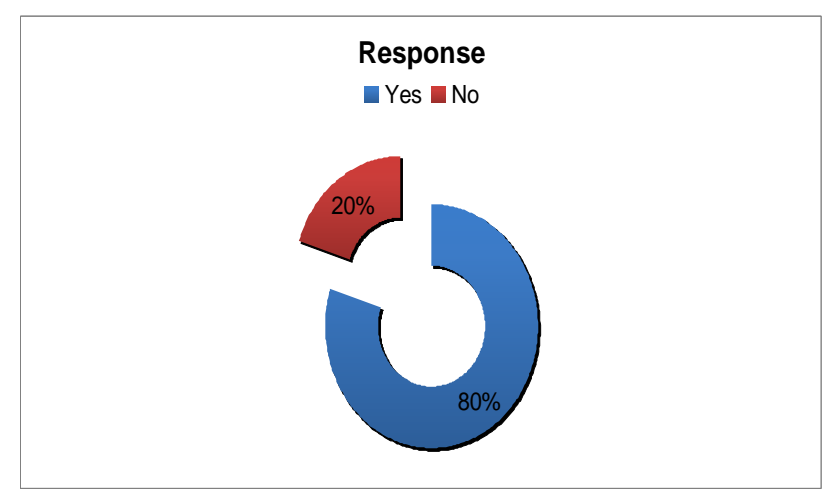

Figure 8

Questionnaire Results: Do you plan your trips ahead of time?

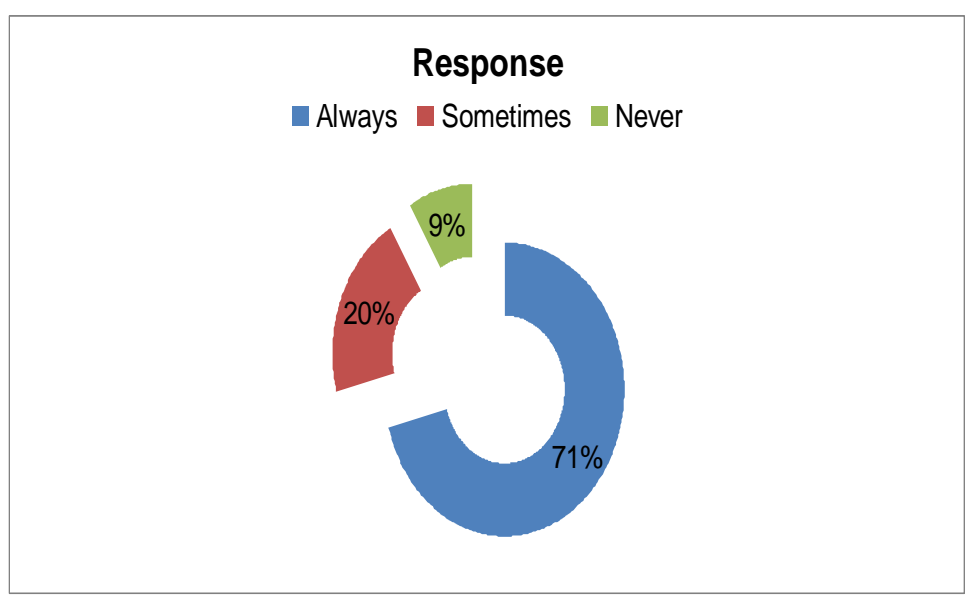

مجلة كلية السباحة والفنادق - جامعة الإسكندرية - سبتمبر • ب. T) (96) 